\title{
Metamorphoses of the WTO: Constructing Global Governance through Trade
}

\author{
Fitri Fadhilla, Ramiaji Kusumawardhana, and Chen Kun Cheng
}

\begin{abstract}
Since its creation in 1995, the World Trade Organization (WTO) has been one of the leading international organizations. We could expect that more countries entered the WTO because of the significance growth on world trade. However, the uniqueness of this organization does not lie on how many members it has or even the fact that trade is increasing rapidly. The creation of this new legal system in the WTO has led other new characteristics of the WTO. With strong legal system, trading among countries can be more predictable and stable which could serve as a basis for economic growth. This is one of the reasons many countries entered or remain to be the WTO member. In this paper that both of these characteristics, which are sourced from the WTO legal framework, contributed to the creation of global governance despite the growing critiques centered on the effectiveness of the WTO. Global governance suggests a world system or world society and used to describe the increasingly regulated character of transnational and international relations. Global governance implies an absence of central authority, and thus the need for collaboration and cooperation among governments and others who seek to encourage common practices and goals in addressing global issues. Even though there exist a large number of critics on the role and effectiveness of the WTO, in this paper focus on the process rather than the outcome. Similar to any problem solving, an outcome may not be preferable to one individual or group but preferable to the other. However, the system has created a forum to facilitate the discussion.
\end{abstract}

Index Terms-Trade, WTO, global governance, GATT.

\section{INTRODUCTION}

Highlight it's been predict that the greater "legalism" of the WTO and the Dispute Settlement Understanding (DSU) will, in particular, encourage more participation by developing countries. The notion of equal legal framework, together with the consensus decision-making mechanism, has also led to a greater participation of members. This has led the increasing role of developing countries that we are seeing currently. In this paper that both of these characteristics, which are sourced from the WTO legal framework, contributed to the creation of global governance despite the growing critiques centered on the effectiveness of the WTO. According to Krahmann (2003) [1], global governance suggests a world system or world society and used to describe the increasingly regulated character of transnational and international relations. In their paper, they also mentioned the global governance definition from Leon Gordenker and Thomas Weiss as follows: "global governance implies an absence of central authority, and thus the need for collaboration and cooperation among

Manuscript received October 9, 2017; revised January 11, 2018.

The authors are with Asia University, Taiwan (e-mail: fie3_fadhilla@yahoo.co.id). governments and others who seek to encourage common practices and goals in addressing global issues." Thus, global governance is not global government but focused on the unity of interest/goals and how to maintain it. This is also aligned with Bull's notion of international order. Bull argued that order is maintained by a sense of common interests in those elementary or primary goals; by rules which prescribe the pattern of behavior that sustains them; and by institutions which make these rules effective. The paper is organized as follows. Part I discussed the metamorphoses of the WTO from GATT. Part II discusses the theories linking the WTO to global governance. This includes the debate on the role of the WTO. Part III discusses what the future would be like on this linkage, then end the article by conclusion.

\section{Metamorphoses OF THE WTO}

\section{A. GATT era}

The General Agreement on Tariffs and Trade (GATT) was originally negotiated in 1947 by twenty-three countries as a provisional trade agreement to lower tariffs. It was originated with the U.S.-led hegemonic order and was transformed as part of the transition to global neoliberalism. The original plan was to establish an International Trade Organization (ITO) for governance of trade. However, the ITO was never succeeded. It was successfully negotiated multilaterally, but the U.S. Congress refused to ratify the ITO Charter due to some controversial provisions (Diebold, 1952) [2]. As a result, signatories remained using temporary arrangement which is the GATT.

The goal of GATT is for members to commit on tariff and other non-tariff barriers reduction. To reach an agreement, members exchange concessions with balanced reciprocity. Members also agreed on the "Most Favored Nation" (MFN) treatment to eliminate discriminatory treatment. It means that all countries which are the recipient of a country's commitment must receive equal trade advantages. This lead to the GATT system of rule-making followed a diplomatic model where agreements were to be concluded in negotiations over the reciprocal concessions each. Contracting Party would take upon itself in return to concessions offered by the other Parties. The agreements, which included general obligations as well as particular assignments to specific countries, would be approved by consensus. Following the initial signing of the GATT in 1947, the Agreement was renegotiated once every few years in "rounds" of multilateral negotiations

However, the GATT was identic with the power-based system, especially with U.S. hegemony. Sen (2003) [3]argued 
that the principles of international trade agreements which set up the notion of reciprocity and most favored nation were originated in US practice. He further argued that most agreements were the political sensitivities of US domestic lobbies on the matter that congressional assent could only be gained. The American market would also be opened up, but only with specific exchanges of concessions with trading partners. In line with this argument, Goldstein (2000) [4]argues that the power-based system has created essential characteristics of the GATT which rest on the insertion of an escape clause that allowed temporary suspension of concessions and the ability to retaliate against members flouting the rules. The following section provides a deeper discussion on the transition from GATT to WTO.

\section{B. From GATT to WTO}

The WTO covered numerous new jurisdictions, required all members to adhere to the rules, and included greatly enhanced enforcement mechanisms that GATT did not attribute with. This in turn has created a new set of environment for the decision making process in the WTO. This is sought to be the key achievement of the creation of a rules-based system for resolving trade disputes, in preference to the power-based system that GATT is attributed with (Lindequie and McGuire, 2007) [5].

The basic rule is that a state could complain that its benefits under GATT had been nullified and impaired by the action of another state. If efforts at consultation and attempts to negotiate a mutually satisfactory solution failed, the Council would convene a GATT panel of experts from countries not involved in the dispute. The chairman of the GATT Council, in consultation with the parties and with the help of the Secretariat's staff, selected the panel to hear the dispute. The panel took evidence, heard argument, and eventually issued a written decision responsive to the complaint. The GATT Secretariat, in particular the Office of Legal Affairs, played a strong role in the decision making process. Their representatives attended all panel meetings, provided guidance on GATT case law, expressed views to panelists, and can also drafted legal opinions. The panel then submitted its decision to the GATT Council for adoption. However, even one vote (including the vote of the party that lost the case), could block approval of the decision and prevent it from becoming "GATT law". Thus the GATT dispute settlement mechanism is usually hard to achieve and many members opt to search for other forums. The decision is also non-binding, in which there is no legal framework ensuring the adoption.

The WTO had a new legal system that differs from its GATT predecessor in five major ways (Shell, 1995) [6]. First, all dispute settlement procedures under the GATT and a variety of other trade-related agreements are brought under a single dispute resolution process overseen by an institution called the WTO "Dispute Settlement Body" (DSB). This ends the potential for forum-shopping within the WTO that exists under current GAIT rules. Second, there are strict timetables for processing disputes and substantial changes in the rules governing the adoption of dispute resolution panel reports. The first stage of the panel process is similar to the old GATT system described above. However, in contrast to the old
GATT system, WTO panel decision should be adopted unless a party to the dispute formally notifies the DSB of its decision to appeal or the DSB decides by consensus not to adopt the report. Thus, dispute resolution decisions will be formally binding on WTO signatory states.

Third, the WTO procedures provide for appeals from panel decisions under the WTO "Appellate Body." The Appellate Body is a permanent, seven-member trade court that will oversee the work of all dispute resolution panels. Judges will be appointed by the DSB and the court will sit in three-judge panels. According to the Uruguay Round agreements, Appellate Body judges are to be people "of recognized authority, with demonstrated expertise in law, international trade and the subject matter of the covered agreements generally". They also should be unaffiliated with any government. Under this third characteristic, the dispute settlement set under the WTO tries to ensure the professionalism and formal legal procedure.

Fourth, the WTO rules expressly stipulate that the defendant must comply with the decision within "a reasonable period of time."' The WTO is empowered to engage in active surveillance of compliance measures to assure that the defendant takes the required steps to remedy its violation. There are detailed mechanisms on which to define "reasonable period of time" for compliance or how to overcome the disagreement about actions taken to comply, but at the end the dispute settlement mechanism has legal framework to ensure that a resolution decision must be complied.

Finally, the WTO legal system takes the form of a pledge by WTO members to refrain from unilateral action in the global trade arena. In a clear attempt to address concerns about the use of domestic legislative schemes, the dispute resolution procedures stipulates that states shall not make any unilateral determinations that treaty violations have occurred or that more than a reasonable period of time has passed for compliance except through recourse to dispute settlement in accordance with the rules and procedures of this Understanding. In addition, states pledge to follow the WTO procedures regarding the suspension of concessions and not to impose sanctions unless they are approved by the DSB.

\section{Legal Framework and Applicability of the Rules}

During the GATT era, the system of rules had little effect on the institutions. It has limited jurisdictions and imposed relatively weak rules and systems of enforcement for its members. Even though the multilateral trade negotiations in GATT has led to quite substantial tariff reductions, particularly after the early 1960 s, but some countries replaced these tariffs with non-tariff barriers to trade, such as import licenses and quotas, "buy-national" procurement regulations, product standards, and government subsidies (Winham, 1986) [7]. These were also accompanied by the generally loose and non-mandatory agreements regulating non-tariff barriers to trade.

The GATT's system of enforcement was also rather weak. Hudec (1993) [8] argued that the effective adjudication was constrained by the principle of consensual decision-making, which gave defendants the ability to delay or block the procedures. Thus, even though the rules applied to all 
members (both developed and developing countries), most countries can find good reasons to avoid the rules. On the one hand, the U.S. government and other wealthy countries managed to exclude many of their key protected industries (including apparel and textiles, steel, and many agricultural products) from the process of trade liberalization. At the same time, developing countries were subject to somewhat more lenient rules than developed countries, and member states were able to opt out of at least some of the agreements regulating non-tariff barriers to trade, which many developing countries initially chose to do (Chorev and Babb, 2009) [9].

The WTO, on the other hand, has a stronger legal framework where the application of rules has become more comprehensive. The Non-Tariff Barriers Agreements that were very loose at the GATT era were established and covered a range of Non-Tariff Barriers application across many sectors on top of the nature of the agreement that it is applied to all members. The WTO now also comprises an integrated and distinctive legal order. For example, today the WTO incorporated an agreement on Intellectual Property Rights (IPR). The WTO also has a "single undertaking" rule which aims to ensure the inclusiveness of all members across different issues. Chorev and Babb (2009) [9] further argued that this affected mainly poor countries, which could no longer excuse themselves from legal obligations too strenuous for their legal systems or stages of economic development. However, on the part of developed countries, the strengthening of the dispute mechanisms has also made them difficult not to comply with their international obligations. Thus, the strong and comprehensive legal framework of the WTO has made countries comply with the rules.

\section{WTO AS A FORM OF GLOBAL GOVERNANCE}

\section{A. Defining Global Governance}

Many scholars have discussed the notion of global governance, however there appears to be an ambiguity among scholar on the definition of global governance, both on the definition of "global" and "governance". The first part discussed who are the actors involved, while the latter discussed the scope of activities. Rosenau (1995) [10]use a very broad term, that is "Systems of rule at all levels of human activity - from family to international organization- in which the pursuit of goals through the exercise of control has transnational repercussions. However, more scholars have tried to narrow the definition based on the two part of the concept: global and governance. On the concept of global, there seems to be an agreement on the different set of actors involved. The global governance does not limit only on state actors, but also non-state actors. Especially with the increasing globalization, government are now interlinked with other governments, international organizations, and nongovernmental organizations (NGOs). Thus, while state continue to play a central role in global governance, international organizations, NGOs, and multinational corporations increasingly participate (Finkelstein, 1995; Krahman, 2003) [1], [11].

On the concept of governance, Krahmann (2003) [1] suggest that global governance is a world system or world society and used to describe the increasingly regulated character of transnational and international relations. In his paper, he mentioned the definition of global governance from Leon Gordenker and Thomas Weiss as follows: “... global governance implies an absence of central authority, and thus the need for collaboration and cooperation among governments and others who seek to encourage common practices and goals in addressing global issues." Finkelstein (1995) [10] emphasizes that governance does not limit to the reaching of decisions about rules, and that it should be stretched beyond rule making. As do governments, the international system also does more than direct the behavior of the relevant actors. Thus governance should be considered to cover the overlapping categories of functions performed internationally, among them: information creation and exchange; formulation and promulgation of principles and promotion of consensual knowledge affecting the general international order; effort to influence the domestic rules and behavior of states, good offices, conciliation, mediation, and compulsory resolution of disputes; adoption of rules, allocation of material and program resources; conducting relief and humanitarian; and most of all is to maintain peace and order. This is aligned with Bull (1893) concept of international society which emphasize the ideas of reformed or improved international society which has led the League of Nations, the United Nations and other general international organization have the role to maintain international order.

Scholars also agreed that the concept of global governance does not mean global government. It focuses on the unity of interest/goals and how to maintain it. This is also aligned with Bull's notion of international order. Bull (1893) argued that order is maintained by a sense of common interests in those elementary or primary goals; by rules which prescribe the pattern of behavior that sustains them; and by institutions which make these rules effective. Thus, drawing from previous literatures, global governance has several characteristics. First, governance does not mean global government. It means that more integrated collaboration and cooperation among actors. Second, its main goal is to maintain international order and peace. Third, its practice covered a range of activities that does not only focus on rule making. It also involved other activities as any sovereign authority does. And lastly, it involves comprehensive actors of government and non-government actors.

\section{B. The WTO and the Concept of Global Governance}

Having the concept of global governance above, we can evaluate whether the WTO fits into those concept or not. However, even if it does not fit, we can evaluate whether the metamorphoses of the WTO from GATT has led to the alignment with those concept. Below are the discussions of each characteristic of global governance, along with its critiques from different scholars.

\section{Concept \#1: WTO is an integrated collaboration and cooperation among actors.}

There are many criticism and skeptical view arise on whether this cooperation can be achieved or not. Especially with the unresolved Doha Round negotiation, many views that a comprehensive range of agreements cannot be achieved 
among all members. Many countries claimed that the gains from trade are not distributed equally for developing countries and the current negotiation agenda is biased against developing countries (Davis and Bermoe, 2009) [12]. On the other side, (Pieterse, 2004) [13] also argues that the United States has long been riding the crest of the wave of globalization but is now experiencing its downsides. What is good for multinational capital is no longer good for the US and the American economy. As the United States can no longer follow the path of unlimited globalization, exporting countries can no longer rely on export-led growth because exports to the US market are not likely to be sustainable. These cases have led to the inward and regional development we are seeing rapidly today, away from the multilateral cooperation the WTO has hoped for.

This also relates to the criticism that the GATT/WTO system is focused only on the rules but not on the outcome (Gerhart, 2002) [14]. For example, he argued that the system espouses reciprocity, but they did not address the problems of poor countries except insofar as the appropriate rules for an "open and non-discriminatory" trading system would help those countries. These skepticisms mainly came from the international relations theory of realism. They argue that states in a realist world marked by interstate anarchy would not find sufficient common ground or trust (Shell, 1995) [6].

However, despite the growing critiques of the WTO as explained above, members continue to make effort towards the WTO in facilitating their interest. The outcomes may not be preferable as the ones pointed out above, however the system has provided a forum to negotiate among members that could further facilitate the discussion to overcome those problems. The system has also has the single undertaking rule to ensure that no members are left behind. Although single undertaking itself has received many critiques, this seems to be the most appropriate mechanism to prevent a sub-set of nations from acting to the detriment of the full membership (Low, 2011). Many have also argued that the GATT/WTO system embodies a mix of certainty and flexibility which reflects the ambiguity of a system. However, this could also be seen as a way to facilitate different interest among countries. The flexibility provided under the WTO is intended to facilitate special cases or will be reduced and eliminated at some point. Thus, this is not something the system is lacking of, rather it is a way the system tries to provide the interest of all its members.

In addition, the strengthening legal framework and the creation of the dispute settlement mechanism should also be seen to facilitate the cooperation among members. With these tools, countries are more predictable and stable in doing trade with other countries. If this were not available, countries are faced with more uncertainty in trading with others, and could result in a more deprivation from trade.

\section{Concept \#2: The goal is to maintain international order and peace.}

WTO is an international organization that brings together two concept of international law. It is a permanent negotiating forum between sovereign states and is therefore a cooperation organization akin to the international conferences under traditional international law. But it also comprises sophisticated dispute settlement mechanism which makes it an integration organization rooted in contemporary international law (Shell, 1995) [6]. The WTO's sophisticated dispute settlement mechanism makes it a distinctive organization and thus comprises a true legal order. With these tools, the WTO is able to better maintain international order and provide peace as the function of global governance. Thus, the WTO remained a source of transnational rules and is likely to represent the global economic governance.

Concerns also raised on the effectiveness of the dispute settlement mechanism. Not surprisingly, wealthy countries have an advantageous position in judicial proceedings (Bown and Hoekman, 2005; Busch and Reinhard 2002) [15], [16]. They have better access to information and legal expertise and greater administrative capacity. Furthermore, they are better able to afford the costs of litigation, and in cases of noncompliance with a negative decision they have a greater capacity to withstand the consequences of retaliation. They also have the benefit of substantive legal rules that reflect their interests.

However, the WTO dispute settlement procedures also provide a forum for weaker countries to raise their concerns (Chorev, 2005) [17]. High startup costs for using trade litigation are indeed a barrier to developing country use of the dispute settlement process. However, the WTO has provided legal assistance from the ACWL (Advisory Center for WTO Law) which plays a complementary role as an external source of experience that increases the use of dispute settlement by its members. Even though this too has received many criticism such as the poor quality, however the experience that the developing countries receive from this practice may reduce its cost in future cases (Lindeque and MicGuire, 2007) [5]. They further argued that dispute initiation from 1975 to 2003 shows that past experience in trade adjudication, as either a complainant or a defendant, increases the likelihood that a developing country will initiate disputes. As weaker countries overcome these initial capacity constraints, they will increasingly benefit from the international legal structures they have joined. This has been shown that some developing countries have been among the most active participants in GATT/WTO adjudication.

Strengthened dispute-resolution mechanism under the WTO has also increased the extent to which governments are "obliged" to maintain their liberal commitments and avoid them for using escape clauses and other loopholes interacted with domestic political realities. The reducing ability of governments to opt out of commitments has the positive effect of reducing the chances that governments will behave opportunistically by invoking criteria for protecting their industries. Thus, the system has now made it difficult for countries including rich countries such as the United States, to violate WTO rules (Chorev, 2005) [17]. This principle is fully respected at the WTO and can be a basis of maintaining legal order and peace.

Concept \#3: It covers a range of activities beyond rule making.

The WTO does not only produce a body of legal rules. (Lamy, 2000) [18] argued that the WTO can be sought as global governance through the following characteristics: the 
WTO system provided a basis for the organization of power, or the elements of consultation and dialogue necessary to securing greater harmony; it offer forum where our members negotiate international agreements which are then adopted; it has a monitoring and surveillance mechanism of member's action; it have a strong mechanism of adjudication and enforcement of members obligation; and have mandate to ensure coherence with some other international organization. This is aligned with the concept of global governance that it should also provide other activities on top of rule making which include among them the information creation and exchange; formulation and promulgation of principles and promotion of consensual knowledge affecting the general international order; effort to influence the domestic rules and behavior of states, good offices, conciliation, mediation, and compulsory resolution of disputes; adoption of rules, allocation of material and program resources.

In addition to the strong mechanism of adjudication and enforcement of members obligation through its sophisticated legal framework and dispute settlement mechanism, the WTO also have a monitoring and surveillance mechanism of member's actions through the Trade Policy Review Mechanism (TPRM) that exist since the GATT era. Thus, the WTO has also functioned in making up a system and governing a community through rule making and other activities.

\section{Concept \#4: It involves comprehensive states and non-states actors.}

Members have increased significantly from the twenty-three GATT members to the 159 WTO members. This shows how the WTO covers almost every state in the world and thus sufficient to be global governance. However, it does not lie on the numbers to construct global governance, but the inclusiveness of these actors. The system has promoted the role of developing countries both in negotiations and dispute settlement.

This more equal participation of its members also relates to the discussion on US hegemony. It has been noted earlier that the initial formation of the WTO was led by US hegemony by incorporating the neoliberal ideas. However, Lindeque and McGuire (2007) [5] argues that there are various stages where the United States might be able to exercise hegemonic power in the WTO but are declining in various stages of negotiation. Significantly, the United States does best in the early phases of a dispute, where politics, not law, is the key governing characteristic. US performance then declines somewhat once the formal process has started as the rules of the game become clearer and apply to both parties.

On the other hand, Cox (1992)[19] argued that the US hegemony may still be sustained because it depends on dominant ideas and collective images the US has. The logic of consensus has only partly constrained the ability of the U.S. government to impose its will on others, but the size of the U.S. economy makes both threats of sanctions and promises of benefits very effective. Thus, the WTO still awards a leading role to the United States but it seems to be declining. The WTO's internal governance system allows members to potentially influence the making and application of rules through rounds of trade negotiations and the dispute resolution mechanism. With the constraints on US hegemony provided by the system, there has been an even greater increasing role of other members. The need to arrive to consensus provides developing countries some bargaining leverage and provided an opportunity to create a coalition of developing countries as we have seen in the current Doha Round negotiations. Thus, the deadlock in the Doha Round may be seen to be a positive sign for the WTO rather than a negative one, as it suggests that the WTO may have the capacity to incorporate and respond to transformations in the economic positions and political interests of member states. The actors involved is not only marked by increasing number of states and its role, but also on the involvement of non-state actors such as other international organizations and nongovernment organizations. The WTO even has a mandate to ensure coherence with some other international organization. There are, however, critiques that suggest governance of global spaces lacks democratic legitimacy where the resolution rest on very limited explicit consent from the affected populations (Axworthy, 2001) [20]. Public participation and public accountability are generally weak. However, this is something natural. It is almost impossible to involve every single actors in the decision making. However, in addition with the states as their representative, the role of NGOs and other international organization has also been an effective way as the representation of these actors.

Furthermore, with the increasing availability of information, domestic actors have more and better information about the distributional implications of commercial agreements. The effect of the legalization can thus be the incentives of domestic groups to mobilize and pressure their governments to adopt policies that favor them. Information on who will gain and lose from some international action will affect the incentives of groups to mobilize for and against trade agreements.

In summary of this section, we can see that although not perfect, the WTO can be considered as constructing global governance through trade. The WTO focused on the unity of interest by cooperation and collaboration, which goals is to ensure international order and peace through activities that consist of rule-making and other activities of governance; and include the participation of both states and non-states actors. It is also noted that this is supported by its sophisticated legal framework and dispute settlement mechanism the WTO has.

\section{HOW FAR WiLl IT Go}

Use it is undeniable that the WTO has received many critiques. Less than a decade ago, market-liberalizing ideas and policies reigned supreme. However, the popularity has declined dramatically lately because the growing skepticism on the practice of neoliberal to economic performance especially for developing countries. Even in the meeting of the Group of 20 (G20) heads of state in the spring of 2009, British Prime Minister Gordon Brown announced the death of "the Washington Consensus"- the famous list of market-liberalizing policy prescriptions that guided the previous 20 years of economic policy (Chorev and Babb, 2009) [9]. 
But overall, the WTO is often criticized for its hypocrisy. That is, its tendency to cater to the interests of protectionist interest groups in developed countries, while preaching the doctrine of "free trade" to others (Stiglitz, 2006)[21]. For example, one of the main disputes in the current round of trade negotiations revolves around agricultural protection. On the one hand, the United States and the European Union cannot agree on reducing their high tariffs on agricultural imports and on lowering their generous subsidies to their farmers and agribusiness. On the other hand, the U.S. objects to a "special safeguard mechanism," designed to protect farmers in the developing world against temporary surges in cut-price imports of cotton and rice (Elliott 2008) [22].

However, the WTO remains active and even growing in some areas: members came into accession increase, the improvement of its legal framework, and the strengthening dispute settlement mechanism. The WTO provides effective incentives for remaining within the system in which the WTO depends on procedural legitimacy. Thus, a disagreement or even stagnation of the discussion in the WTO cannot be the bases to judge that the WTO is ineffective. The strength of the WTO is on its process, rather that its outcome. The WTO relies on its claim to procedural fairness. Although outcome is as important as the process, outcome may be seen differently from different perspective. Any outcome may be good in the view of one side, but bad in view of others. And even though there have been serious complaints, the WTO's formally equal system of rules makes it more difficult to criticize its on procedural grounds. In addition, creating global governance is not something instant. The process takes time and perhaps the overall 65 years time frame since the creation of GATT is not sufficient.

According to Rodrik (2000) [23], even though we don't see significant improvement on the outcome from the WTO by looking at many countries that are still imposing barriers and that international economic integration remains remarkably limited, he argues that if we see a longer time period, in the next 100 years he would predict global federalism/governance became stronger. He based this prediction based on several aspects. First, continuing technological progress will both foster international economic integration and remove some of the traditional obstacles to global government. Second, short of global wars or natural disasters of major proportions, it is hard to envisage that a substantial part of the world's population will want to give up the goodies that an increasingly integrated world market can deliver. Third, hard-won citizenship rights are also unlikely to be given up easily, keeping pressure on the politicians to remain accountable to the wishes of their electorate. Therefore, we may need more time to create the global governance, but looking at the process of the WTO, I argued that the WTO is on track.

\section{REFERENCES}

[1] E. Krahmann, "National, regional, and global governance," Global Governance, vol. 9, 2003.

[2] D. William, "The end of the ITO," International Finance Section, Princeton University, vol. 16, 1952.

[3] B. B. Chitrabhan and S. Sen, "Consumer-company identification: A framework for understanding consumers' relationships with companies," Journal of marketing, vol. 67, no. 2, pp. 76-88, 2003.
[4] Goldstein and L. L. Martin, "Legalization, trade liberalization, and domestic politics: A cautionary note," International Organization, vol. 54, no. 3, pp. 603-632, Summer 2000.

[5] J. Lindeque and S. McGuire, "The United States and trade disputes in the world trade organization: Hegemony constrained or confirmed?' Management International Review, vol. 47, no. 5, 2007.

[6] G. R. Shell, "Trade legalism and international relations theory: An analysis of the world trade organization," Duke Law Journal, March 1995.

[7] G. R. Winham, International Trade and the Tokyo Round Negotiation, 1986.

[8] H. E. Robert, D. L. M. Kennedy, and M. Sgarbossa, "A statistical profile of GATT dispute settlement cases: 1948-1989," Minn. J. Global Trade 2, 1993.

[9] N. Chorev and S. Babb, "The crisis of neoliberalism and the future of international institutions: A comparison of the IMF and the WTO," June 2009.

[10] J. N. Rosenau, "Governance in the twenty first century," Global Governance, Winter 1995

[11] L. Finkelstein, "What is Global Governance?" Global Governence, 1995.

[12] C. L. Davis and S. B. Bermeo, "Who files? Developing country participation in GATT/WTO adjudication," The Journal of Politics, vol. 71, no. 3, pp. 1033-1049, July 2009.

[13] J. N. Pieterse, "Towards democratic globalization: To WTO or not to WTO?" Development and Change, vol. 35, no. 5, pp. 1057-1063.

[14] P. M. Gerhart, "Slow transformations: The WTO as a distributive organization," October 2002.

[15] B. P. Chad and B. M. Hoekman, "WTO dispute settlement and the missing developing country cases: Engaging the private sector," Journal of International Economic Law, vol. 8, no. 4, pp. 861-890, 2005.

[16] M. L. Busch and E. Reindhart, "Developing countries and general agreement on tariffs and trade/world trade organization dispute settlement," Journal of World Trade, 2003.

[17] C. Nitsan. "The institutional project of neo-liberal globalism: The case of the WTO," Theory and Society, vol. 34, no. 3, pp. 317-355, 2005.

[18] L. Pascal. "Europe and the future of economic governance," JCMS Journal of Common Market Studies, vol. 42, no.1, pp. 5-21, 2004.

[19] C. W. Robert, "Global perestroika," Socialist register, vol. 28, 1992.

[20] L. Axworthy, "Human security and global governance," Global Governance, vol. 7, 2001

[21] J. E. Stiglitz, "Stability with growth: Macroeconomics, liberalization and development," Oxford University Press on Demand, 2006.

[22] L. T. Elliott, "WTO talks collapse after India and China clash with America over farm products," The Guardian, p. 22, 2008.

[23] R. Francisco and D. Rodrik, "Trade policy and economic growth: A skeptic's guide to the cross-national evidence," NBER Macroeconomics Annual, vol. 15, pp. 261-325, 2000.

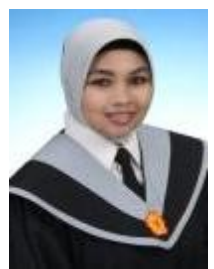

Fitri Fadhilla was born on May 18, 1987 in Bukkittinggi, Indonesia. She has completed her bachelor degree in University of Muhammadiyah Yogyakarta and also holds the M.B.A. from Asia University, Taiwan. Currently she is pursuing her PhD in business administration at Asia University Taiwan, R.O.C.

Ms. Fadhilla is also a lecturer at Open University for Taiwan branch. Open University is one of Indonesian government program for Indonesian citizen who want to pursue higher education, especially for Indonesian worker who work abroad.

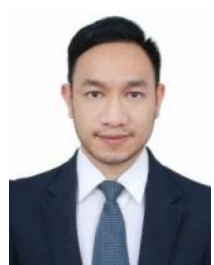

Ramiaji Kusumawardhana was born on January 28 1986 in Bogor City, Indonesia, he has completed his B.Sc.(Agr.), majoring in agribusiness management at Bogor Agriculture University Bogor Indonesia and also hold the M.A. in international trade from Ajou University, South Korea. Currently he is pursuing his $\mathrm{PhD}$ in business administration in Asia University Taiwan, R.O.C.

Mr. Kusumawardhana currently working in the Ministry of Trade of the Republic of Indonesia, has appointed as Foreign Trade Policy Analyst in 2009. He contributed to the promotion of trade agenda in global forums such as WTO negotiations, APEC, G20 and others bilateral He also was appointed as one of the core team for the WTO MC-9 in Bali and in charge for the formulation on the trade facilitation, policy and practices in line with multilateral trade rules and standstill commitments. His 
last position is the Head Section of Export of Industry and Mining Products. Currently he's also active in learning deep and wider knowledge of WTO by joining the special training held by the Ministry of Trade and registered in WTO E-Learning Program, WTO distance Learning and also generalist and specialist course program. Mr. Kusumawardhana is also a chairman of Delima Harapan Bangsa Foundation, a social foundation to supports education program and disaster

Management program.
Kun Cheng Chen currently is an associate professor at College of Management of Asia University, Taiwan. He graduated from the National Chiao Tung University, Institute of Management of Technology, Ph.D. He has an experience in the Caoyang University of Technology Mr. Lin has a research interests in management of technology, innovation and development management, technology forecast, technology preview. 